\title{
Short communication: Milk protein genetic variation and casein haplotype structure in the Original Pinzgauer cattle
}

\author{
A. Caroli, ${ }^{*}$ R. Rizzi, $†$ G. Lühken, $\ddagger$ and G. Erhardt ${ }^{1}$ \\ *Dipartimento di Scienze Biomediche e Biotecnologie, Università degli Studi di Brescia, Viale Europa 11, 25123 Brescia, Italy \\ †Dipartimento di Scienze e Tecnologie Veterinarie per la Sicurezza Alimentare, Università degli Studi di Milano, Via Trentacoste 2, 20134 Milano, \\ Italy \\ ‡Institute of Animal Breeding and Genetics, Justus-Liebig-University, Ludwigstrasse 21b, D-35390 Giessen, Germany
}

\section{ABSTRACT}

Milk protein genetic polymorphisms are often used for characterizing domesticated mammalian species and breeds, and for studying associations with economic traits. The aim of this work was to analyze milk protein genetic variation in the Original Pinzgauer, a dual-purpose (dairy and beef) cattle breed of European origin that was influenced in the past by human movements from different regions as well as by crossbreeding with Red Holstein. A total of 485 milk samples from Original Pinzgauer from Austria $(\mathrm{n}=275)$ and Germany $(\mathrm{n}=$ $210)$ were typed at milk proteins $\alpha_{S 1}$-casein, $\beta$-casein, $\kappa$-casein, $\alpha$-lactalbumin, and $\beta$-lactoglobulin by isoelectrofocusing to analyze the genetic variation affecting the protein amino acid charge. The Original Pinzgauer breed is characterized by a rather high genetic variation affecting the amino acid charge of milk proteins, with a total of 15 alleles, 12 of which were found at a frequency $>0.05$. The most polymorphic protein was $\beta$-casein with 4 alleles detected. The prevalent alleles were $C S N 1 S 1^{*} B, \quad C S N 2{ }^{*} A^{2}, C S N 1 S 2^{*} A, C S N 3^{*} A$, $L G B^{*} A$, and $L A A^{*} B$. A relatively high frequency of $C S N 1 S 2{ }^{*} B$ (0.202 in the whole data set) was found, mainly occurring within the $C-A^{2}-B-A$ haplotype (in the order CSN1S1-CSN2-CSN1S2-CSN3), which seems to be peculiar to the Original Pinzgauer, possibly because the survival of an ancestral haplotype or the introgression of Bos indicus.

Key words: milk protein, Original Pinzgauer cattle, $\alpha_{\mathrm{s} 2}$-casein, haplotype

The analysis of milk protein genetic variation is a useful tool for characterizing domesticated mammalian species and breeds, with the aim of studying the evolution of animal resources and milk protein genes (Ceriotti et al., 2004; Jann et al., 2004; Ibeagha-Awemu et al., 2007). The 2 main whey proteins, $\alpha-\mathrm{LA}$ and $\beta-\mathrm{LG}$, are coded by the genes $L A A$ and $L G B$, respectively,

Received June 29, 2009.

Accepted November 9, 2009.

${ }^{1}$ Corresponding author: Georg.Erhardt@agrar.uni-giessen.de whereas $\alpha_{\mathrm{S}^{-}} \mathrm{CN}, \alpha_{\mathrm{S} 2}-\mathrm{CN}, \beta-\mathrm{CN}$, and $\kappa-\mathrm{CN}$ are coded by the genes $C S N 1 S 1, C S N 1 S 2, C S N 2$, and $C S N 3$, respectively. These 6 structural genes are affected by genetic variation that can modify the amino acid structure of the specific protein, possibly resulting in differences in the isoelectric points and electric charges of the genetic variants (Grosclaude, 1988; Farrell et al., 2004). Such biochemical variation can produce important effects on protein function as well as on milk composition and quality (Di Stasio and Mariani, 2000; Martin et al., 2002; Heck et al., 2009).

Another key aspect of milk protein variants is the tight linkage existing among the $4 \mathrm{CN}$ genes within a 250-kb cluster (Ferretti et al., 1990; Threadgill and Womack, 1990). The CN alleles are thus most often inherited as a "haplotype" including, in order, CSN1S1, CSN2, CSN1S2, and CSN3. Local breeds often offer a reservoir of specific alleles and $\mathrm{CN}$ haplotypes, allowing deeper genetic data mining of milk protein variation.

The aims of this work were 1) to study the genetic variation affecting the amino acid charge of milk protein genes in the Original Pinzgauer cattle, with particular attention to the occurrence of rare variants and 2) to compare 2 different breeding areas in terms of the variability of milk protein.

The Original Pinzgauer is a dual-purpose (dairy and beef) red and white cattle breed of European origin. About 500 AD, Alpine herdsmen had begun to develop a breed of red and white cattle from the native red Bavarian cattle. These early cattlemen selected animals that could withstand the harsh conditions and produce meat and milk (http://www.ansi.okstate.edu/breeds/ cattle/pinzgauer/). This medium-sized breed takes its name from Pinzgau in Salzburg, Austria, and the herd book dates back to the 1700s (Pinzgauer Cattle, 2008). The breed was influenced in the past by human movements from different regions and also by crossbreeding with Red Holstein, resulting in the current Pinzgauer breed. Original Pinzgauer are characterized by a Red Holstein contribution of less than $6 \%$.

The census of the Original Pinzgauer population was 423 animals in Germany in 2006 (http://www.genres. 
Table 1. Frequencies of milk protein alleles, identified by isoelectric focusing, in Original Pinzgauer in the whole data set (overall) and in the Austrian and German samples

\begin{tabular}{llccc}
\hline Locus $^{1}$ & Allele & Overall $(\mathrm{n}=485)$ & Austria $(\mathrm{n}=275)$ & Germany $(\mathrm{n}=210)$ \\
\hline CSN1S1 & $B$ & 0.730 & 0.709 & 0.757 \\
& $C$ & 0.270 & 0.291 & 0.243 \\
CSN2 & $A^{1}$ & 0.357 & 0.342 & 0.376 \\
& $A^{2}$ & 0.572 & 0.589 & 0.550 \\
& $B$ & 0.015 & 0.011 & 0.021 \\
& $C$ & 0.056 & 0.058 & 0.053 \\
CSN1S2 & $A$ & 0.798 & 0.755 & 0.855 \\
& $B$ & 0.202 & 0.245 & 0.145 \\
CSN3 & & & & 0.736 \\
& $A$ & 0.728 & 0.722 & 0.262 \\
& $B$ & 0.266 & 0.269 & 0.002 \\
LAA & & 0.006 & & 0.009 \\
& $A$ & 0.002 & 0.004 & 1.000 \\
& $B$ & 0.998 & 0.996 & 0.151 \\
& $A$ & 0.140 & 0.131 & 0.849 \\
\hline
\end{tabular}

${ }^{1}$ CSN1S1, CSN1S2, CSN2, and CSN3 code for $\alpha_{\mathrm{S1}^{-}} \mathrm{CN}, \alpha_{\mathrm{S} 2} \mathrm{CN}, \beta-\mathrm{CN}$, and $\kappa-\mathrm{CN}$, respectively; $L A A$ and $L G B$ code for $\alpha$-LA and $\beta-\mathrm{LG}$, respectively.

de/CF/tgrdeu/charakterisierung.cfm?idrasse $=171)$, and 4,833 animals in Austria in 2007 (http://www.oengene.at/index.jsp?catId=33) compared with a worldwide population of 1 million Pinzgauers distributed in 25 countries, and mainly used for meat production (http://www.pinzgauer-cattle.com/). The endangered status of the breed is further motivation for the genetic characterization of the current population at milk protein genes.

A total of 485 individual milk samples were randomly collected from animals of the Original Pinzgauer breed reared both in Austria $(\mathrm{n}=275)$ and Germany $(\mathrm{n}=210)$ and analyzed by isoelectrofocusing (IEF) according to Erhardt et al. (1998). Allele frequencies were estimated by direct count. Deviations from Hardy-Weinberg equilibrium were estimated by the Genepop program (version 1.2; Raymond and Rousset, 1995). The $F$-statistics were estimated by FSTAT (version 1.2; Goudet, 1995). The haplotype frequencies (CSN1S1-CSN2-CSN1S2-CSN3) were estimated using the EH program (Xie and Ott, 1993). The program provides haplotype frequencies expected under the independence hypothesis (independent frequencies, IF) and estimated taking association into account (association frequencies, $\mathbf{A F}$ ). The program uses an iterative maximum-likelihood algorithm under the assumption of Hardy-Weinberg equilibrium. In addition, it gives $x^{2}$ values for this comparison, which were used to calculate $P$-values for the hypothesis that the estimated values (AF) differ from the expected values (IF).
After extraction of genomic DNA from milk somatic cells (Lühken et al., 2009), the coding region of exon IV of $C S N 3$ was sequenced in 59 Original Pinzgauer carrying $C S N 1 S 2^{*} B$, to differentiate the $C S N 3$ alleles $A, B$, $C, F, G, H, I$, and $J$ (Prinzenberg et al., 2008). For this purpose, exon IV was amplified by PCR (Prinzenberg et al., 1999) using a modified reverse primer (5'-gttgtcttctttgatgtctccttagag). Sequencing of PCR products from both sides with one of the PCR primers each and sequence analysis was done as described by Lühken et al. (2009).

Allele frequencies of milk protein genes are shown in Table 1. Fifteen alleles were found from the 22 alleles identifiable by IEF. This number is slightly larger than in other breeds analyzed by the same method and similar in sample size; that is, Italian Friesian (13 alleles), Italian Brown (14 alleles), and Reggiana (13 alleles; Caroli et al., 2004). Only one deviation from Hardy-Weinberg equilibrium was observed, namely at CSN1S2 gene in the German population, which had an excess of homozygous genotypes. This deviation was not observed in the combined population. Individual genotypes for each locus are available on request.

Two variants were found at CSN1S1, CSN1S2, and $L G B$, whereas $L A A$ was almost fixed for the $B$ allele. The most polymorphic gene was CSN2, with 4 alleles detected $\left(A^{2}, A^{1}, C\right.$, and $B$, in decreasing order of frequency). A rather high frequency was found for CSN $1 S 1^{*} C$, which is usually more common in Bos indicus than in Bos taurus (Formaggioni et al., 1999). 
Three alleles were detected at CSN3. The prevalent allele was $C S N 3^{*} A$, whereas $C S N 3^{*} B$, which is the most favorable CSN3 variant from the point of view of milk rennet clotting properties (Di Stasio and Mariani, 2000), occurred at a frequency of 0.266. In addition, $C S N 3^{*} E$ was found at a very low frequency. The presence of $C S N 3^{*} E$ in the Original Pinzgauer is an indicator for the influence of Red Holstein genes in some animals, as already described for the Pinzgauer (Erhardt, 1996). Most of the former Original Pinzgauer underwent improvement by using Red Holstein semen in past breeding programs, although the influence of this improvement is difficult to quantify. Genetic markers can provide a useful tool for tracing Red Holstein introgression. In fact, a sample of animals from the current Pinzgauer was grouped with German and Austrian Holsteins in a phylogenetic study based on microsatellites, whereas animals of the Original Pinzgauer were clustered separately from the other breeds (Baumung et al., 2008).

Surprisingly, $C S N 3^{*} G$ was no longer present after its first discovery in the breed (Erhardt, 1996) and the detection of unfavorable effects on milk rennet clotting properties described (Erhardt et al., 1997). This rare variant occurred in one sire (unpublished results), whose genes were most probably lost or extremely diluted in the actual Original Pinzgauer population as a consequence of genetic drift.

A relatively large frequency was found for the CSN1S2* $B$ allele, which was more common in the Austrian sample. The $\mathrm{F}_{\mathrm{ST}}$ statistics significantly differed from zero $(P<0.001)$ only for $C S N 1 S 2$, as the consequence of the different distribution of $C S N 1 S 2^{*} A$ and $C S N 1 S 2{ }^{*} B$ in the 2 populations; $C S N 1 S 2{ }^{*} B$ is more common in Bos indicus breeds (Formaggioni et al., 1999). Grosclaude et al. (1976) found both $C S N 1 S 2^{*} A$ and $B$ variants in Nepalese Bos taurus and Bos indicus populations. Merlin and Di Stasio (1979) described some unknown $\alpha_{S_{2}}-\mathrm{CN}$ bands with a smaller electrophoretic mobility than the ones produced by the predominant CSN1S2*A in the Pinzgauer cattle reared in Italy. Possibly, such bands corresponded to $C S N 1 S 2^{*} B$. Chianese et al. (1988) demonstrated the occurrence of this variant in the Podolian, an Italian Bos taurus breed. IbeaghaAwemu et al. (2007) characterized $C S N 1 S 2{ }^{*} B$ by identifying a $\mathrm{C} \rightarrow \mathrm{T}$ substitution in the 17 th nucleotide of exon 3 , leading to a Ser $\rightarrow$ Phe exchange in the eighth amino acid of the mature protein. The same authors found $C S N 1 S 2^{*} B$ to be widely distributed not only in Bos indicus breeds but also in European cattle breeds, particularly of southeastern origin, with the largest frequency (0.133) in the Turkish Gray Steppe. In the Original Pinzgauer, $C S N 1 S 2^{*} B$ frequencies were larger than in the Turkish Gray Steppe, in both Austrian and German populations.

Another sign of Bos indicus introgression or conservation of ancient germplasm is the presence of $L A A^{*} A$, although limited, in the Austrian population. This allele was found in all zebu breeds at frequencies ranging from 0.082 to 0.405 , whereas its frequency was $<0.01$ in taurine breeds except Turkish Gray Steppe and Anatolian Black (Ibeagha-Awemu et al., 2007). Unlike $C S N 1 S 2{ }^{*} B, L A A^{*} A$ was mainly lost or not spread in the Original Pinzgauer, perhaps because of unfavorable or absent effects on the breed's performance, low frequency in the ancestral germplasm, or genetic drift.

Haplotype frequencies at the CSN1S1-CSN2CSN1S2-CSN3 cluster are reported in Table 2. A total of 48 possible haplotypes resulted from the combination of 2-4-2-3 alleles considered. Except for haplotype $B-A^{2}-A-A$, a large difference was observed between IF and AF. In fact, the association test performed by the EH program was statistically significant $(P<0.0001)$, indicating high linkage disequilibrium $(\mathbf{L D})$ at the $\mathrm{CN}$ cluster. This result can be a consequence, again, of the genetic drift in the small population, as well as of favorable effects of particular haplotypes on the breed performance and fitness. The predominant haplotype was $B-A^{1}-A-A$, followed by $B-A^{2}-A-A$ and $C-A^{2}-B-A$. With regard to the least frequent $\mathrm{CN}$ alleles observed in the breed, $C S N 2^{*} C$ mainly occurred in $B-C-A-B$, but also in $B-C-B-B$ haplotypes, whereas $C S N 2{ }^{*} B$ was carried by $B-B-A-B$, and $C S N 3^{*} E$ by $B-A^{1}-A-E$.

Considering only haplotypes with frequency $>5 \%$, 4 gametic types were observed between $C S N 1 S 1$ and $C S N 3$ ( $B-A, C-A, B-B$, and $C-B$ ). These types were also observed among 411 individuals in which the gametic phase could be directly inferred, thus excluding an artifact of haplotype inference. The most likely explanation for this pattern is recombination within the casein cluster (Jann et al., 2002; Prinzenberg et al., 2003). Although it is unlikely that recombination occurred within Pinzgauer populations because of extensive $\mathrm{LD}$, it is possible that recombination may have happened in the progenitors of the Original Pinzgauer or before the domestication event. Under this second scenario, recombinant haplotypes were captured during Pinzgauer breed formation.

Haplotypes carrying $C S N 1 S 2^{*} B$, in particular $C$ - $A^{2}$ $B$ - $A$, were predominant in the Austrian sample, reflecting the prevalence of this "Bos indicus" allele in this breeding area. In contrast, $C-A^{2}-A-A$, which is the $C-A^{2}$ $B-A$ counterpart carrying the "Bos taurus" CSN1S2*A, was predominant in Germany. The difference between the 2 breeding areas might be the consequence of a long breeding period when exchange of genetic material was 
Table 2. Casein haplotype frequencies in the Original Pinzgauer in the whole data set (overall) and in the Austrian and German samples ${ }^{1}$

\begin{tabular}{|c|c|c|c|c|c|c|c|c|c|}
\hline \multicolumn{4}{|c|}{$\mathrm{CN}$ gene $^{2}$} & \multicolumn{2}{|c|}{ Overall $(\mathrm{n}=485)$} & \multicolumn{2}{|c|}{ Austria $(\mathrm{n}=275)$} & \multicolumn{2}{|c|}{ Germany $(\mathrm{n}=210)$} \\
\hline$B$ & $A^{1}$ & $A$ & $A$ & 0.15 & 0.26 & 0.13 & 0.24 & 0.18 & 0.28 \\
\hline$C$ & $A^{2}$ & $B$ & $A$ & 0.02 & 0.16 & 0.03 & 0.20 & 0.01 & 0.12 \\
\hline$B$ & $A^{1}$ & $A$ & $B$ & 0.06 & 0.08 & 0.05 & 0.07 & 0.06 & 0.09 \\
\hline C & $A^{2}$ & $A$ & $B$ & 0.03 & 0.07 & 0.03 & 0.07 & 0.08 & 0.06 \\
\hline$B$ & $C$ & $B$ & $B$ & & 0.01 & & 0.03 & & \\
\hline$B$ & $A^{1}$ & $B$ & $A$ & 0.04 & 0.01 & 0.04 & 0.02 & 0.03 & 0.01 \\
\hline$B$ & $B$ & $A$ & $B$ & & 0.01 & & 0.01 & & 0.01 \\
\hline$B$ & $A^{2}$ & $B$ & $A$ & 0.06 & 0.01 & 0.07 & & 0.04 & 0.01 \\
\hline$B$ & $A^{1}$ & $A$ & $E$ & & 0.01 & & 0.01 & & \\
\hline$B$ & $A^{2}$ & $B$ & $B$ & 0.02 & 0.01 & 0.03 & 0.01 & 0.02 & 0.01 \\
\hline$C$ & $A^{1}$ & $A$ & $B$ & 0.02 & & 0.02 & & 0.02 & \\
\hline$C$ & $A^{1}$ & $B$ & $A$ & 0.01 & & 0.02 & & 0.01 & \\
\hline$C$ & $A^{1}$ & $B$ & $B$ & 0.01 & & 0.01 & & & \\
\hline$C$ & $A^{2}$ & $B$ & $B$ & 0.01 & & 0.01 & & 0.01 & \\
\hline$C$ & $C$ & $A$ & $A$ & 0.01 & & 0.01 & & 0.01 & \\
\hline
\end{tabular}

${ }^{1} \mathrm{IF}=$ independent frequencies; $\mathrm{AF}=$ association frequencies; only haplotypes with at least an AF or IF value $>0.00$ are shown. Haplotypes are reported in descending $\mathrm{AF}$ order in the overall group; blank $=0.00$.

${ }^{2}$ CSN1S1, CSN1S2, CSN2, and CSN3 code for $\alpha_{\mathrm{S} 1}-\mathrm{CN}, \alpha_{\mathrm{S} 2}-\mathrm{CN}, \beta-\mathrm{CN}$, and $\kappa-\mathrm{CN}$, respectively.

limited because of geographic restrictions, genetic drift effect, or different selection strategies carried out by the breeders.

The prevalence of $C S N 1 S 2^{*} B$ in the $C-A^{2}-B-A$ haplotype could indicate this combination as typical of the Original Pinzgauer, as a consequence of the survival of an ancestral haplotype or the introgression of Bos indicus. This hypothesis is supported by the high frequency (0.42) of the $C S N 3^{*} H$ allele observed after the DNA sequencing of 59 Original Pinzgauer individuals extracted from the whole data set on the basis of the occurrence of $C S N 1 S 2^{*} B$ in their genotype. In fact, $C S N 3^{*} H$ is another "zebu-specific" allele, also found by Ibeagha-Awemu et al. (2007) in the taurine breeds carrying $C S N 1 S 2^{*} B$. Indeed, it would be more precise to define such alleles as "zebu-peculiar" instead of "zebuspecific," because of their recurrent presence in Bos taurus germplasm. No further $C S N 3$ allele was detected at the DNA level in addition to the IEF identifiable variants and $C S N 3^{*} H$.

In addition, the hypothesis of ancestral polymorphism retention should be more carefully considered as an alternative to Bos indicus hybridization. In fact, $C S N 1 S 2^{*} B, L A A^{*} A$, and $C S N 3^{*} H$ might represent ancestral polymorphisms common to both Bos indicus and Bos taurus. In this case, genetic drift or selection increasing the frequency of $C S N 1 S 2^{*} B$ in the Original Pinzgauer breed could mimic Bos indicus introgression. However, whereas the occurrence of $C S N{ }^{*} H$ in the breed can be explained by $\mathrm{LD}$ at the $\mathrm{CN}$ haplotype, the simultaneous presence of $L A A^{*} A$, even if at a low frequency, could be a further hint of Bos indicus introgression caused by the independent segregation of the $L A A$ and $\mathrm{CN}$ cluster, harbored on chromosomes 5 and 6, respectively (Hayes et al., 1993; Popescu et al., 1996).

More information can be derived from the analysis of CN haplotype variability. Mahé et al. (1999) described the predominance of $C S N 1 S 1{ }^{*} C-C S N 2{ }^{*} A^{2}-C S N 3^{*} A$ haplotype in zebu breeds in an electrophoretic study at the protein level. Jann et al. (2004) confirmed these findings at the DNA level, allowing discrimination of the 3 alleles $\operatorname{CSN}_{3}{ }^{*} A, \operatorname{CSN}^{*} H$, and $C S N 3^{*} A^{I}$, which co-migrate as $C S N 3^{*} A$ if analyzed at the protein level by electrophoresis or IEF. The occurrence of haplotypes $C S N 1 S 1^{*} C-C S N 2{ }^{*} A^{2}-C S N 3^{*} A^{I}$ and $C S N 1 S 1^{*} C$ $C S N 2 * A^{2}-C S N 3{ }^{*} H$ indicated the introgression of Bos indicus in southern and eastern European cattle breeds (Jann et al., 2004). In the Original Pinzgauer, the high frequency (0.2 in the overall sample) of the haplotype $C S N 1 S 1^{*} C-C S N 2 * A^{2}-C S N 3^{*} A$ provides a further argument for Bos indicus introgression, as suggested 
by previous reports on the basis of other markers in taurine breeds (e.g., Cymbron et al., 1999; Loftus et al., 1999; Beja-Pereira et al., 2006). However, further investigation is needed in the Bos genus at the CN haplotype level including the simultaneous detection of $C S N 1 S 2^{*} B, C S N 3^{*} H$, and $C S N 3^{*} A^{I}$.

Data on the Pinzgauer reared in Italy highlighted the distance from other brachyceros Italian breeds on the basis of milk protein genes (Pieragostini et al., 2002). Conversely, Astolfi et al. (1983) did not find particular differences for Italian Pinzgauer from the mountain Brown breed group on the basis of immunological and biochemical markers. The same authors proposed an introgression of Bos primigenius from the Middle East around the third millennium $\mathrm{BC}$. The hypothesis of eastern introgression into Central Europe cattle is also supported by a work based on mitochondrial haplotypes, which indicated the introduction, during Roman times or earlier, of diverse female lineages from the domestication center or by later admixture in Switzerland (Schlumbaum et al., 2006). This introgression might have involved the progenitors of the Original Pinzgauer, too, with a particular effect on the CN haplotype. Nevertheless, the retention of ancient milk protein polymorphisms could be a possible alternative to the Bos indicus hybridization hypothesis.

In conclusion, the Original Pinzgauer breed is characterized by an interesting variation affecting the amino acid charge of milk proteins. The frequency of $C S N 1 S 2{ }^{*} B$ is relatively high in this breed and is mainly linked with the $C-A^{2}-B-A$ haplotype. The wide distribution of this allele in European Bos taurus breeds and its high frequency in the Original Pinzgauer demonstrate that $C S N 1 S 2^{*} B$ has to be considered in milk protein studies in taurine breeds. Association analyses with milk production traits are necessary to investigate whether the maintenance of ancestral haplotypes provided the Original Pinzgauer with enhanced fitness or otherwise affected the productivity of this local breed.

\section{ACKNOWLEDGMENTS}

We thank the farmer organizationsTZD Irmgard Mitterwallner LKV Salzburg and Erwin Zierer LKV Bayern e.V. for providing samples and data and VIGONI project 2007-2008 for partial financial support.

\section{REFERENCES}

Astolfi, P., G. Pagnacco, and C. R. Gugliemino-Matessi. 1983. Phylogenetic analysis of native Italian cattle breeds. J. Anim. Breed. Genet. 100:87-100.

Baumung, R., S. Manatrinon, F. Fischerleitner, I. Medugorac, and A. Preinerstorfer. 2008. https://www.dafne.at/dafne_plus_
homepage/download.php?t=ProjectReportAttachment\&k=1310 Accessed April, 2009.

Beja-Pereira, A., D. Caramelli, C. Lalueza-Fox, C. Vernes, N. Ferrand, A. Casoli, F. Goyache, L. Royo, S. Conti, M. Lari, A. Martini, L. Ouragh, A. Magid, A. Atash, A. Zsolnai, P. Boscato, C. Triantaphylidis, K. Ploumi, L. Sineo, F. Mallegni, C. Taberlet, G. Erhardt, L. Sampietro, J. Bertranpetit, G. Barbujani, G. Luikart, and G. Bertorelle. 2006. The origin of European cattle: New evidence from modern and ancient DNA. Proc. Natl. Acad. Sci. USA 103:8113-8118.

Caroli, A., S. Chessa, P. Bolla, E. Budelli, and G. C. Gandini. 2004. Genetic structure of milk protein polymorphisms and effects on milk production traits in a local dairy cattle. J. Anim. Breed. Genet. 121:119-127.

Ceriotti, G., D. Marletta, A. Caroli, and G. Erhardt. 2004. Milk protein polymorphism in taurine (Bos taurus) and zebu (Bos indicus) populations bred in hot climate. J. Anim. Breed. Genet. 121:404-415.

Chianese, L., A. Di Luccia, R. Mauriello, L. Ferrara, G. Zehender, and F. Addeo. 1988. Polimorfismo biochimico delle proteine del latte in bovine di razza Podolica. Zoot. Nutriz. Anim. 14:189-197.

Cymbron, T., R. T. Loftus, M. I. Malheiro, and D. G. Bradley. 1999. Mitochondrial sequence variation suggests an African influence in Portuguese cattle. Proc. R. Soc. Lond. B Biol. Sci. 266:597-603.

Di Stasio, L., and P. Mariani. 2000. The role of protein polymorphism in the genetic improvement of milk production. Zoot. Nutr. Anim. 26:69-90.

Erhardt, G. 1996. Detection of a new k-casein variant in milk of Pinzgauer cattle. Anim. Genet. 27:105-107.

Erhardt, G., J. Juszczak, L. Panicke, and H. Krick-Saleck. 1998. Genetic polymorphism of milk proteins in Polish Red cattle: A new genetic variant of $\beta$-lactoglobulin. J. Anim. Breed. Genet. 115:63-71.

Erhardt, G., E. M. Prinzenberg, J. Buchberger, H. Krick-Saleck, I. Krause, and M. Miller. 1997. Bovine k-casein G detection, occurrence, molecular genetic characterization, genotyping and coagulation properties. Pages 328-329 in Proc. IDF Milk Protein Polymorphism Seminar II. International Dairy Federation, Brussels, Belgium.

Farrell, H. M. Jr., R. Jimenez-Flores, G. T. Bleck, E. M. Brown, J. E. Butler, L. K. Creamer, C. L. Hicks, C. M. Hollar, F. Ng-KwaiHang, and H. E. Swaisgood. 2004. Nomenclature of the proteins of cows' milk — Sixth revision. J. Dairy Sci. 87:1641-1674.

Ferretti, L., P. Leone, and V. Sgaramella. 1990. Long range restriction analysis of the bovine casein genes. Nucleic Acids Res. 18:68296833 .

Formaggioni, P., A. Summer, M. Malacarne, and P. Mariani. 1999. Milk protein polymorphism: Detection and diffusion of the genetic variants in Bos genus. Ann. Fac. Med. Vet. Univ. Parma 127-165.

Goudet, J. 1995. FSTAT, Version 1.2, A computer program to calculate F-statistics. J. Hered. 86:485-486.

Grosclaude, F. 1988. Le polymorphisme génétique des principales lactoprotéines bovines. Relations avec la quantité, la composition et les aptitudes fromagères du lait. INRA Prod. Anim. 1:5-17.

Grosclaude, F., M. F. Mahé, J. C. Mercier, J. Bonnemaire, and J. H. Teissier. 1976. Polymorphisme des lactoprotéines de Bovinés Népalais. II. Polymorphisme des caséines "os-mineures"; le locus as2-Cn est-il lié aux loci as1-Cn, $\beta$-Cn et k-Cn? Ann. Genet. Sel. Anim. 8:481-491.

Hayes, H., E. Petit, C. Bouniol, and P. Popescu. 1993. Localisation of the alpha-S2- casein gene (CASAS2) to the homologous cattle, sheep and goat chromosome 4 by in situ hybridisation. Cytogenet. Cell Genet. 64:282-285.

Heck, J. M. L., A. Schennink, H. J. F. van Valenberg, H. Bovenhuis, M. H. P. W. Visker, J. A. M. van Arendonk, and A. C. M. van Hooijdonk. 2009. Effects of milk protein variants on the protein composition of bovine milk. J. Dairy Sci. 92:1192-1202.

Ibeagha-Awemu, E. M., E.-M. Prinzenberg, O. C. Jann, G. Lühken, A. E. Ibeagha, X. Zhao, and G. Erhardt. 2007. Molecular characterization of bovine CSN1S2B and extensive distribution of 
zebu specific milk protein alleles in European cattle. J. Dairy Sci. 90:3522-3529.

Jann, O. C., E. M. Ibeagha-Awemu, C. Özbeyaz, P. Zaragoza, J. L. Williams, P. Ajmone-Marsan, J. A. Lenstra, K. MoazamiGoudarzi, and G. Erhardt. 2004. Geographic distribution of haplotype diversity at the bovine casein locus. Genet. Sel. Evol. $36: 243-257$.

Jann, O. C., H. Brandt, J. L. Williams, P. Ajmone-Marsan, P. Zaragoza, C. Ozbeyaz, and G. Erhardt. 2002. Intragenic haplotypes at the bovine CSN1S1 locus. Arch. Tierz. Dummerstorf 45:13-22.

Loftus, R. T., O. Ertugrul, A. H. Harba, M. A. A. El-Barody, and D. E. MacHugh. 1999. A microsatellite survey from a centre of origin: The Near East. Mol. Ecol. 8:2015-2022.

Lühken, G., A. Caroli, E. M. Ibeagha-Awemu, and G. Erhardt. 2009 Characterization and genetic analysis of bovine $\alpha_{\mathrm{s} 1}$-casein $I$ variant. Anim. Genet. 40:479-485.

Mahé, M. F., G. Miranda, R. Queval, A. Bado, P. S. Zafindrajaona, and F. Grosclaude. 1999. Genetic polymorphism of milk proteins in African Bos taurus and Bos indicus populations. Characterization of variants $\alpha \mathrm{S} 1-\mathrm{Cn} \mathrm{H}$ and $\kappa-\mathrm{CN}$ J. Genet. Sel. Evol. 31:239-253.

Martin, P., M. Szymanowska, L. Zwierzchowski, and C. Leroux. 2002 The impact of genetic polymorphisms on the protein composition of ruminants' milks. Reprod. Nutr. Dev. 42:433-459.

Merlin, P., and L. Di Stasio. 1979. Polimorfismo della as2-caseina nella razza bovina Pinzgau. Proc. Salvaguardia genetica e prospettive per il recupero zootecnico di razze, popolazioni autoctone italiane, Foligno, Italy.

Pieragostini, E., A. Di Luccia, A. Caroli, and R. Rullo. 2002. Lactoprotein polymorphism in Italian cattle breeds. L'industria del Latte 28:17-31.
Pinzgauer Cattle. 2008: http://www.rarebreeds.co.nz/pinzgauer.html Accessed March 24, 2009

Popescu, C. P., S. Long, P. Riggs, J. Womack, S. Schmutz, R. Fries, and D. S. Gallagher. 1996. Standardization of cattle karyotype nomenclature: Report of the committee for the standardization of the cattle karyotype. Cytogenet. Cell Genet. 74:259-261.

Prinzenberg, E.-M., H. Jianlin, and G. Erhardt. 2008. Genetic variation in the $\mathrm{k}$-casein gene (CSN3) of Chinese yak (Bos grunniens) and phylogenetic analysis of CSN3 sequences in the genus Bos. J. Dairy Sci. 91:1198-1203.

Prinzenberg, E.-M. I. Krause, and G. Erhardt. 1999. SSCP analysis at the bovine CSN3 locus discriminates six alleles corresponding to known protein variants $(\mathrm{A}, \mathrm{B}, \mathrm{C}, \mathrm{E}, \mathrm{F}, \mathrm{G})$ and three new DNA polymorphisms (H, I, A1). Anim. Biotechnol. 10:49-62.

Prinzenberg, E. M., C. Weimann, H. Brandt, J. Bennewitz, E. Kalm, M. Schwerin, and G. Erhardt. 2003. Polymorphism of the bovine CSN1S1 promoter: Linkage mapping, intragenic haplotypes and effects on milk production traits. J. Dairy Sci. 86:2696-2705.

Raymond, M., and F. Rousset. 1995. Genepop (version 1.2): Population genetics software for exact test and ecumenicism. J. Hered. $86: 248-249$.

Schlumbaum, A., M. Turgay, and J. Schible. 2006. Short communication: Near east mtDNA haplotype variants in Roman cattle from Augusta Raurica, Switzerland, and in the Swiss Evolène breed. Anim. Genet. 37:373-375.

Threadgill, D. W., and J. E. Womack. 1990. Genomic analysis of the major bovine milk protein genes. Nucleic Acids Res. 18:69356942.

Xie, X., and J. Ott. 1993. Testing linkage disequilibrium between a disease gene and marker loci. Am. J. Hum. Genet. 53(Suppl.):1107. 